\title{
NON-PARAMETRIC TESTS APPLIED TO REPORTED CASES OF DENGUE IN THE SOUTHEAST REGION OF BRAZIL
}

\author{
TESTES NÃO-PARAMÉTRICOS APLICADOS A CASOS DE DENGUES \\ REPORTADOS NA REGIÃO SUDESTE DO BRASIL
}

\section{José Francisco de OLIVEIRA-JÚNIOR ${ }^{1}$; Givanildo de GOIS ${ }^{2}$; Elania Barros Da SILVA ${ }^{3}$; Carlos Antonio SILVA JUNIOR ${ }^{4}$; Paulo Eduardo TEODORO ${ }^{5}$}

1. Instituto de Ciências Atmosféricas (ICAT), Universidade Federal de Alagoas (UFAL), Maceió, AL, Brasil; 2. Escola de Engenharia Industrial Metalúrgica de Volta Redonda, Centro Tecnológico, Universidade Federal Fluminense (UFF), Volta Redonda, RJ, Brasil; 3. Secretaria Municipal de Saúde de Capela, Capela, AL, Brasil; 4. Universidade do Estado de Mato Grosso (UNEMAT), Alta Floresta, MT, Brasil; 5. Universidade Federal de Mato Grosso do Sul (UFMS), Chapadão do Sul, MS, Brasil.

\begin{abstract}
Dengue is one of the biggest problems of global public health in developing and underdeveloped countries. Nowadays, researchers in climate changes are concerned about the impact of these changes on human health, particularly with increased this epidemic. Dengue is among the largest public health problems in Brazil and is higher in the months with high temperatures, which is the Aedes aegypti's reproductive period climax. Reported dengue cases via DATASUS from 1994 to 2014 were analyzed. Mann-Kendall (MK), Run and Pettit nonparametric tests; were applied to time series. The run test indicated that the time series is homogenous and persistence free. There is a non-significant trend of increase of a number of reported dengue cases only in Rio de Janeiro. Based on the test, three positive trends were identified in the time series of São Paulo, Minas Gerais and the Espírito Santo States of dengue cases reported in Southeast of Brazil. Pettitt test was able to identify the years classified as El Niño events and that had a significant impact on the increase of dengue cases in the southeastern region of Brazil.
\end{abstract}

KEYWORDS: Infectious disease. Climatic elements. Statistical methods. Meteorological systems. Climate change

\section{INTRODUCTION}

Dengue is one of the biggest global public health problems in developing and underdeveloped countries (BHATT et al., 2016). Nowadays, climate change researchers are concerned about the impact of these changes on human health, particularly with the increasing epidemics of dengue, Zika virus and Chikungunya around the world (COSTELLO, et al. 2009; MASSAD, et al. 2010; COLÓN-GONZÁLEZ, et al. 2013). Along with global warming in recent decades, there was an increase of these pandemic disease through infectious vector-borne diseases, among which dengue plays a significant role (HUSAIN and CHAUDHARY, 2008; MORIN, et al. 2013). The occurrence of this disease has substantially grown year after year, and currently, about 50 to 100 million people are estimated to have been infected worldwide (MURRAY et al., 2013; WHO, 2015; BHATT, et al. 2016). These mosquitoes have great adaptability to urban areas and need reservoirs and containers with static, preferably clean water to lay their eggs, followed by rainfall and continued high air temperature for their development (CAMPBELL, et al. 2015).

Dengue epidemics in Brazil are higher in the months with high temperatures, which is the Aedes aegypti's reproductive period climax. Vector metabolism rate increases in these months, which shortens their life cycle in up to eight days or extends it in up to 22 days in cold months (MARZOCHI, 2004). The replication and maturation of the virus into an insect (extrinsic period) is also accelerated with a rise in air temperature (CÂMARA et al. 2009; MASSAD et al., 2011). Worldwide, there are four types of dengue: DEN-1, DEN-2, DEN-3, and DEN-4. The persistence and progression of these viruses are conditioned to the survival and reproduction of their vector in the environment (CÂMARA et al., 2009).

In Brazil, education, food, hygiene, health care and social relations have a strong impact on the population health, but they also help determine the incidence and expansion of endemic diseases (VIANA and IGNOTTI, 2013). These factors associated with meteorological variables such as air temperature, air relative humidity, rainfall, air pressure and wind regime indirectly affect the population health (infectious diseases carried by vectors such as air, water, soil and food), because the human body is in constant contact with atmospheric environment through thermal, hydric and gaseous exchanges (MORIN et al., 2013; CAMPBELL et al., 2015).

There is a substantial increase in the number of cases of dengue reported in the summer, due to high temperatures and increased rainfall rates contributing to 
the mosquito's life cycle. There is also a greater exposure of the population to vector attacks in the summer because high temperatures encourage people to go for outdoor walks and to wearless protective clothing (MAGALHÃES and ZANELLA, 2015). However, the occurrence of cases in other seasons of the year has been observed by the Ministry of Health (MS) (BARCELLOS and LOWE, 2013; VIANA and IGNOTTI, 2013), in recent years, based on symptomatology.

Several types of researches on dengue in some Brazilian regions were carried out on an individual basis (OLIVEIRA and VALLA, 2001; MARZOCHI, 2004; CÂMARA et al., 2009; MASSAD et al., 2010; LOWE et al., 2012). These studies have associated the weather phenomena (rain, air temperature, relative humidity) with the number of reported cases and incidence rate of dengue. However, it has been demonstrated that the highest incidence rate of reported cases of dengue occurs during the rainy season, followed by a rise in the air temperature, which increases Aedes aegypti's longevity as well as the possibility of the virus transmission (BARCELLOS and LOWE, 2013; MURRAY et al. 2013).
However, there are only a few studies relating the dengue vector and the climatic variables (rain and air temperature) (MASSAD et al. 2010; SHEPARD et al., 2013) to the population data across Brazil. Therefore, the aim of this study was to evaluate reported cases of dengue in Brazil from 1994 to 2014 by using statistical techniques.

\section{MATERIAL AND METHODS}

\section{Study Area}

The Southeast region of Brazil occupies approximately $924620 \mathrm{~km}^{2}$, being the most populous of Brazil with 85 million people. It is composed of four states: Espírito Santo, Minas Gerais, Rio de Janeiro and São Paulo (Figure 1). The relief is quite bumpy, with a predominance of plateaus. The climate is tropical, between hot and temperate, with large local variations. SUS Department of Informatics (Unified Health System) from Brazil provided the data of reported dengue cases in the Southeastern region of Brazil of the time series from 1994-2014 (DATASUS, 2015).

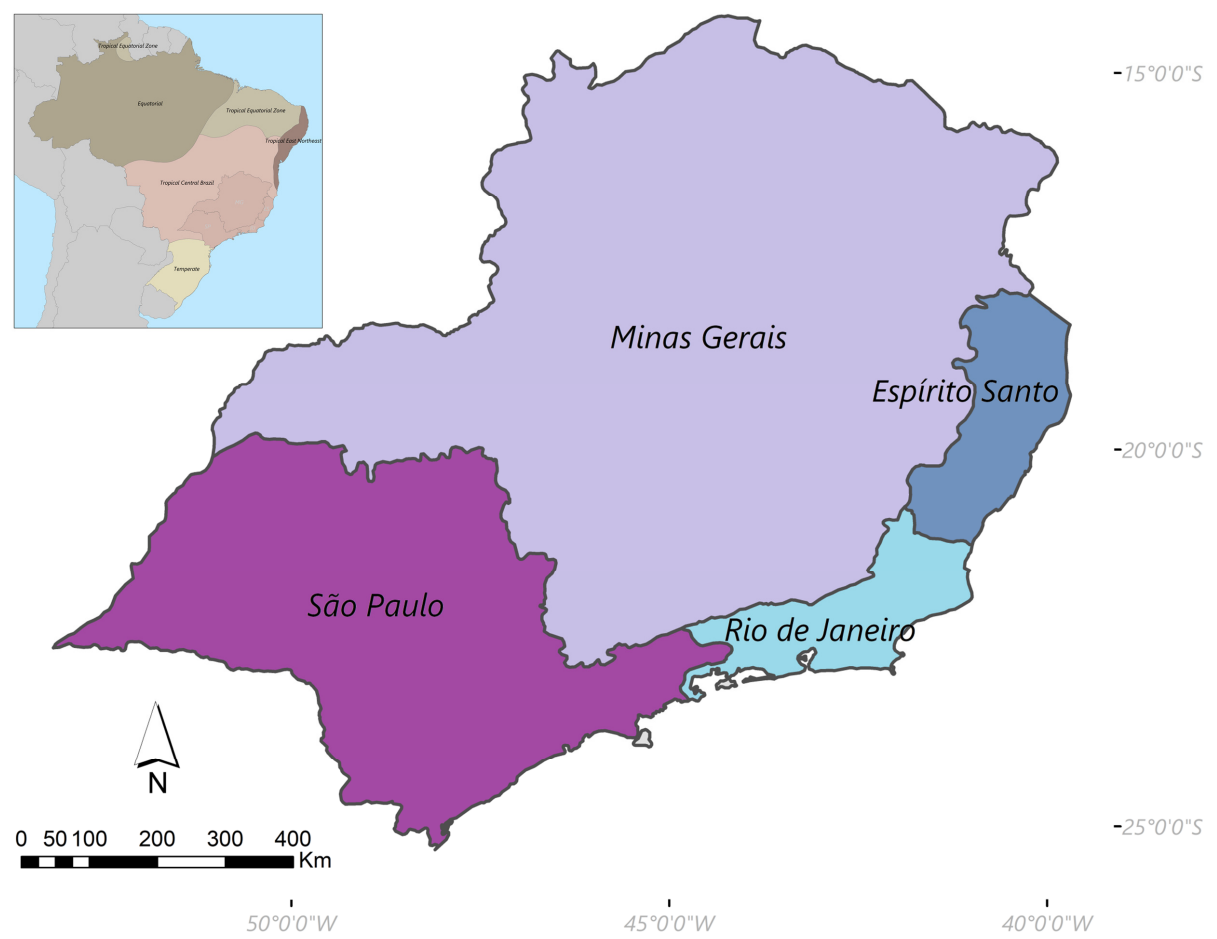

Figure 1. Location and states that make up the Southeast region of Brazil.

\section{Statistical analysis}

Time series of reported dengue cases were evaluated as the occurrence of randomness. We performed the counting the number of oscillations of the values above and below the median, and then applied the Run test. The run test evaluated the number of oscillations within the distribution range considered normal. Higher values indicate several oscillations, and low values indicate a deviation from the median in the period recorded. If the sequence contains $N_{l}$ symbols of a type, and $N_{2}$ symbols of another (and $N_{l}$ and $N_{2}$ are not very low), the sampling distribution of the total number of Runs can be approximated by the normal distribution with mean. This value was compared with $Z$ calculated 
values for the normal distribution. For the significance level at 5\%, $Z$ calculated is between -1.96 and 1.96 . If $\mathrm{Z}$ calculated is higher than the adopted value, the null hypothesis should be rejected in the adapted series.

After, we applied Mann-Kendall (MK) test (MK) (MANN, 1945; KENDALL, 1975), which considers the stability hypothesis of the occurrence of successive and independent values with the probability distribution remaining the same. MK test is the most appropriate method for the approximate location and detection of the starting point of a trend in the time series, particularly of reported dengue cases. Based on $Z_{M K}$ statistics, we decided to accept or reject the null hypothesis $H_{0}$, i.e., the hypothesis is accepted when the time series has no tendency (for $p$ value $>\alpha$ ), and rejected in favor of the alternative hypothesis $H_{1}$ when there is a tendency to $p$ value $<\alpha$ in the time series. We adopted a significance level at $5 \%$ for this study (Table 1).

Table 1. Interpretation of $Z_{M K}$ trend at confidence interval -1.96 to +1.96 .

\begin{tabular}{ll}
\hline Interpretation & Scales \\
\hline Significant Trend (Increase or Decrease) - Sti & $Z_{M K} \geq+1.96$ \\
Non-significant Trend of Increase - NSti & $0<Z_{M K}<+1.96$ \\
Without trend - Wt & $Z_{M K}=0$ \\
Non-significant Trend of Decrease - NStd & $-1,96<Z_{M K}<0$ \\
Significant Trend of Decrease -Std & $Z_{M K} \leq-1.96$ \\
\hline
\end{tabular}

Results will be analyzed according to the sign of $Z$ statistics that indicate that positive values $(Z>0)$ show an increasing trend and negative values a decreasing trend $(Z<0)$ time series of reported dengue cases occurred in Brazil. Estimating the magnitude of the time series trend of reported dengue cases increased or decreased refers to the inclination that can be estimated by the least squares method (MMQ) of inclination $(\beta)$. However, this value calculated by linear regression (YUE et al., 2003; AHMED et al., 2014) may deviate from the true value of the line inclination in the presence of outliers in the data. The result of the pre-bleached time series is the combination of time series, including the initial trend, but without data self-correlation. All steps were followed in the study and, therefore, MK test can be applied to time series.

Reported dengue data were submitted to PETTITT (1979) nonparametric test, which enables identifying the year of occurrence of an abrupt change in time series. We used a Mann-Whintney test version, $n$ which verifies whether two samples $X_{1}, \ldots, X_{t}$ and $X_{t+1}, \ldots, X_{T}$ belongs to the same population. MK, Pettit and Run tests were calculated using the software environment $R$ version 3.2.2 with the use of the annual data series ( $R$ DEVELOPMENT CORE TEAM, 2011).

\section{RESULTS AND DISCUSSION}

The highest reported number of dengue cases in Southeast of Brazil per state were in Rio de Janeiro $(1,261,021$ cases, $14.86 \%)$, Minas Gerais $(1,197,515$ cases, $14.11 \%)$, São Paulo $(1,161,520$ cases, 13.69\%), and Espírito Santo (379,917 cases, $4.48 \%$ ) - (Figure 2). These states have metropolitan regions (MR) densely populated and highly urbanized, thus, contributing to the significant increase of dengue cases in Brazil (IBGE, 2015). These regions are associated with the ineffectiveness of public health policies and uncontrolled urbanization that help the development and proliferation of the vector (MAGALHÃES and ZANELLA, 2015). Therefore, it is possible to affirm that dengue cases and environmental conditions followed by people's habits in the states are strongly linked since the areas are densely urbanized and have increased population density in the last two censuses 2001-2010 (IBGE, 2015). According to BARCELLOS and LOWE (2014), the mosquito transmitter is easily found in major and warm cities. Outbreaks concentrations over the previously mentioned states are due to climate regime and socioeconomic causes (VIANA and IGNOTTI, 2013). 


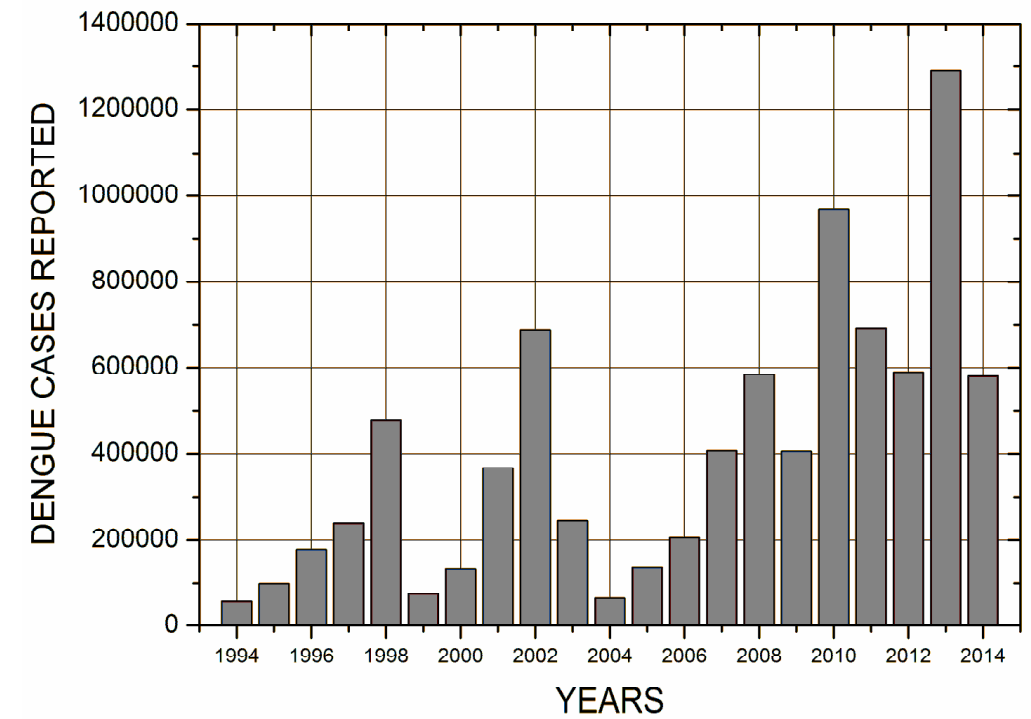

Figure 2. Total annual dengue cases reported in Southeast of Brazil from 1994-2014. Source: DATASUS (2015).

Time series oscillations analysis for dengue cases reported in Southeast of Brazil based on Run test has shown that the determined $\mathrm{Z}$ value was within the confidence interval (Table 1) on $5 \%$ of

probability. Based on the results, the time series is considered free of temporal persistence and homogeneous (Table 2).

Table 2. Run test $\left(\mathrm{Z}_{\mathrm{cal}}\right)$ of the number of reported dengue cases in the Southeast of Brazil at confidence interval -1.96 to +1.96 .

\begin{tabular}{lll}
\hline ID & States & $\begin{array}{l}\text { Run test } \\
\mathbf{Z}_{\text {cal }}\end{array}$ \\
\hline 1 & Minas Gerais & -1.49 \\
2 & Espírito Santo & -1.49 \\
3 & Rio de Janeiro & -0.63 \\
4 & São Paulo & -1.06 \\
\hline
\end{tabular}

There is a non-significant trend of increase (NSti) of a number of reported dengue cases only in Rio de Janeiro, according to the condition, $Z>0$ and $p$-value $>0.05$ probability (Table 3 ). Based on the test, three positive trends were identified in the time series of dengue cases reported in Southeast of Brazil. The Minas Gerais and Espirito Santo States showed the same values for $Z_{c a l}$ (1.49). That means that there was a slight increase in dengue cases reported in the period from 1994 to 2014. It worth pointing out that NSti was growing in the states identified by the MK test and that new public policy measures are needed to contain the growth of this disease. Significant increase in the magnitude of the number of dengue cases reported at regional level recorded by $S_{e}$ method. At the state level, the states that stood out were São Paulo (4,151 cases per year), Minas Gerais (2,904 cases per year), and Espírito Santo (1,092 cases per year).

Table 3. Trend of reported dengue cases by $M K$ test, $Z$ score, trend magnitude estimate by $S_{e}$ method in the respective region, Southeast of Brazil from 1994 to 2014.

\begin{tabular}{lllll}
\hline ID & States & $\boldsymbol{Z}$ score & $\boldsymbol{p}$-value & $S_{e}$ \\
\hline 1 & Minas Gerais & 3.77 & 0.000 & 2.904 \\
2 & Espírito Santo & 1.96 & 0.050 & 1.092 \\
3 & Rio de Janeiro & 0.15 & 0.880 & 0.312 \\
4 & São Paulo & 2.45 & 0.014 & 4.151 \\
\hline
\end{tabular}


Pettitt test (Table 4) has shown the existence of both situations, increase and a non-significant decrease in dengue cases reported in Brazil. The years identified in time series with significant abrupt changes were classified as moderate and neutral El
Niño events (CPTEC, 2015). The cycles were in the years 2004-2007, have reached most states of Brazil in relation to dengue cases and corroborate the results obtained by descriptive and exploratory statistics previously performed.

Table 4. Values obtained from Pettitt test ( $K, p$-value and years) for the respective region Southeast of Brazil from 1994 to 2014.

\begin{tabular}{llccc}
\hline & & \multicolumn{3}{c}{ Pettitt test } \\
\cline { 3 - 4 } ID & States & $\boldsymbol{K}$ & $\boldsymbol{p}$-value & Years \\
\hline 1 & Minas Gerais & 84 & 0.025 & 2007 \\
2 & Espírito Santo & 58 & 0.250 & 2007 \\
3 & Rio de Janeiro & 28 & 1.232 & 2006 \\
4 & São Paulo & 70 & 0.097 & 2005 \\
\hline
\end{tabular}

El Niño causes negative rainfall anomalies in the Southeast of Brazil. These rainfall anomalies are encouraged by a disturbance in $\mathrm{CW}$ and $\mathrm{CH}$ over the eastern Pacific and on SA, as well as by Rossby wave in South SA (Grimm, 2003). Both the summer and the rainy season (in the tropics) that reach most of Brazil, there is an inter-annual variability of rainfall due to El Niño, which in its turn had a significant impact on the increase of dengue cases in some regions of the country during the study period.

\section{CONCLUSIONS}

The southeastern region of Brazil shows a significant increase in dengue cases in the last 20 years, except for the State of Rio de Janeiro.
Pettitt test was able to identify the years classified as El Niño events and that had a significant impact on the increase of dengue cases in the southeastern region of Brazil.

\section{ACKNOWLEDGMENTS}

The authors acknowledge the Departamento de Informática do SUS - Sistema Único de Sáude (DATASUS) and Instituto Brasileiro de Geografia e Estatística and National by the data availability of reported dengue cases in Brazil. To research M.Sc. Jefferson Francisco de Oliveira, in memorian, by an idea for the paper.

RESUMO: A dengue é um dos maiores problemas de saúde pública global em países em desenvolvimento e subdesenvolvidos. Hoje em dia, os pesquisadores em mudanças climáticas estão preocupados com o impacto dessas mudanças na saúde humana, particularmente com o aumento dessa epidemia. A dengue está entre os maiores problemas de saúde pública no Brasil e é maior nos meses com altas temperaturas, que é o clímax do período reprodutivo do Aedes Aegypti. Foram analisados relatórios de casos de dengue via DATASUS de 1994 a 2014. Testes não paramétricos de Mann-Kendall (MK), Run e Pettit; foram aplicadas em séries temporais. O teste Run indicou que a série temporal é homogênea e sem persistência. Existe uma tendência não significativa de aumento do número de casos de dengue relatados apenas no Rio de Janeiro. Com base no teste, três tendências positivas foram identificadas na série temporal de casos de dengue de São Paulo, Minas Gerais e Espírito Santo relatados no Sudeste do Brasil. O teste de Pettitt foi capaz de identificar os anos classificados como eventos de El Niño e que tiveram um impacto significativo no aumento de casos de dengue na região sudeste do Brasil.

PALAVRAS-CHAVE: Doenças infecciosas. Elementos climáticos. Métodos estatísticos. Sistemas meteorológicos. Mudanças climáticas. 


\section{REFERENCES}

AHMED, S. I.; RUDRA, R.; DICKINSON, T.; AHMED, M. Trend and periodicity of temperature time series in Ontario. American Journal of Climate Change, Hubei Province, v. 3, p. 272-288, 2014.

BARCELLOS, C.; LOWE, R. Expansion of the dengue transmission area in Brazil: the role of climate and cities. Tropical Medicine and International Health, Rockville Pike, v. 19, n. 2, p. 159-168, 2014.

BHATT, S.; GETHING, P. W.; BRADY, O. J.; MESSINA, J. P.; FARLOW, A. W.; MOYES, C. L.; DRAKE, J. M.; BROWNSTEIN, J. S.; HOEN, A. G.; SANKOH, O.; MYERS, M. F.; GEORGE, D. B.; JAENISCH, T. W.; WINT, G. R.; SIMMONS, C. P.; SCOTT, T.W.; FARRAR, J. J.; HAY, S. I. The global distribution and burden of dengue. Nature, San Francisco, v. 496, n. 7446, p.504-507, 2013. https://doi.org/10.1038/nature12060

CÂMARA, F. P.; GOMES, A. F.; SANTOS, G. T.; CÂMARA, D. C. P. Clima e epidemias de dengue no Estado do Rio de Janeiro. Revista da Sociedade Brasileira de Medicina Tropical, Uberaba, v. 42, n. 2, p. 137-140, 2009. https://doi.org/10.1590/S0037-86822009000200008

CAMPBELL, L. P.; LUTHER, C.; MOO-LLANES, D.; RAMSEY, J. M.; DANIS-LOZANO, R.; PETERSON, A. T. Climate change influences on global distributions of dengue and chikungunya virus vectors. Philosophical Transaction of the Royal Society B, London, v. 370, n. 1665, p. 20140135, 2015.

COLÓN-GONZÁLEZ, F. J.; FEZZI, C.; LAKE, I. R.; HUNTER, P. R. The Effects of Weather and Climate Change on Dengue. PLoS Neglected Tropical Diseases, Rockville Pike, v. 7, n. 11, p. e2503, 2013.

COSTEllO, A.; ABBAS, M.; ALLEN, A.; BALL, S.; BELLAMY, R.; FRIEL, S,; GRACE, N.; JOHNSON, A.; KETT, M.; LEE, M.; LEVY, C.; MASLIN, M.; MCCOY, D.; MCGUIRE, B.; MONTGOMERY, H.; NAPIER, D.; PAGEL, C.; PATEL, J.; OLIVEIRA, J. A. P.; REDCLIFT, N.; REES, H.; ROGGER, D.; SCOTT, J.; STEPHENSON, J.; TWIGG, J.; WOLFF, J.; PATTERSON, C. Managing the health effects of climate change. The Lancet, Reino Unido, v. 373, n. 9676, p. 1693-1733, 2009.

CPTEC - CENTRO DE PREVISÃO DO TEMPO E ESTUdOS ClimÁticos (2015). ENOS. http://enos.cptec.inpe.br/. Acesso em: 04 de fevereiro.

DATASUS - DEPARTAMENTO DE INFORMÁTICA DO SUS (2015). Informações de Saúde. http://www2.datasus.gov.br/DATASUS/index.php. Acesso em: 13 março.

EVERITT, B. S.; DUNN, G. Applied multivariate analysis. Edward Arnold, London, 400 p., 1991.

HUSAIN, T.; CHAUDHARY, J. R. Human helath risk assessment due to global warming - A case study of the Gulf countries. International Journal of Environmental Research Public Health, Basel, v. 5, n. 4, p.204212, 2008. https://doi.org/10.3390/ijerph5040204

IBGE - INSTITUTO BRASILEIRO DE GEOGRAFIA E ESTATÍSTICA. Área Territorial Oficial e Censo Demográfico Populacional do $\quad$ Brasil. http://www.ibge.gov.br/home/geociencias/cartografia/default_territ_area.shtm. Acesso em: 02 fev 2015.

KENDALL, M. G. Rank Correlation Methods, $4^{\text {th }}$ ed., Charles Griffin: London, 1975.

LOWE, R.; BAILEY, T. C.; STEPHENSON, D. B.; JUPP, T. E.; GRAHAM, R. J.; BARCELlOS, C.; CARVALHO, M. S. The development of an early warning system for climate-sensitive disease risk with a focus on dengue epidemics in Southeast Brazil. Statistics in Medicine, Rockville Pike, v. 32, n. 5, p. 864-883, 2012. 
MAGALHÃES, G. B.; ZANELLA, M. E. The variability climate and frequency of dengue in Fortaleza, CE, Brazil. REDE - Revista Eletrônica do PRODEMA, Fortaleza, v. 9, n.1 , p. 35-50, 2015.

MANN, H. B. Non-parametric test against trend. Econometrica, New York, v. 13, n. 3, p. 245-259, 1945.

MARZOCHI, K. B. F. Dengue endêmico: o desafio das estratégias de vigilância. Revista da Sociedade Brasileira de Medicina Tropical, Uberaba, v. 37, n. 5, p. 413-415, 2004. https://doi.org/10.1590/S003786822004000500009

MORIN, C. W.; COMRIE, A. C.; ERNST, K. Climate and Dengue Transmission: Evidence and Implications. Environmental Health Perspectives, New York, v. 121, n. 11-12, p. 1264-1272, 2013. https://doi.org/10.1289/ehp.1306556

MURRAY, N. E. A.; QUAM, M. B.; WILDER-SMITH, A. Epidemiology of dengue: past, present and future prospects. Clinical Epidemiology, Rockville Pike, v. 5, n. 1, p. 299-309, 2013.

OLIVEIRA, R. M.; VALLA, V. V. As condições e as experiências de vida de grupos populares no Rio de Janeiro: repensando a mobilização popular no controle do dengue. Caderno de Saúde Pública, Rio de Janeiro, v. 17, suppl., p. 77-88, 2001.

PETTITT, A. N. A non-parametric approach to the change-point problem. Applied Statistics, New York, v. 28 , n. 2, p. 126-135, 1979. https://doi.org/10.2307/2346729

R DEVELOPMENT CORE TEAM. R: A language and environment for statistical computing. R Foundation for Statistical Computing, Vienna, Austria. ISBN 3-900051-07- 0, URL http://www.R-project.org. 2011.

SHEPARD, D. S.; UNDURRAGA, E. A.; HALASA, Y. A. Economic and Disease Burden of Dengue in Southeast Asia. PLoS Neglected Tropical Diseases, Rockville Pike, v. 7, n. 2, p. e2055, 2013.

STEWART IBARRA, A. M.; RYAN, S. J.; Beltrán, E.; Mecy Silva, A. M. Dengue Vector Dynamics (Aedes aegypti) Influenced by Climate and Social Factors in Ecuador: Implications for Targeted Control. PLoS ONE, v. 8, n. 11, p. e78263, 2013. https://doi.org/10.1371/journal.pone.0078263

VIANA, D. V.; IGNOTTI, E. A ocorrência da dengue e variações meteorológicas no Brasil: revisão sistemática. Revista Brasileira de Epidemiologia, São Paulo, v. 16, n. 2, p. 240-256, 2013. https://doi.org/10.1590/S1415-790X2013000200002

WHO - WORLD HEALTH ORGANIZATION. Dengue and severe dengue. Fact sheet No. 117. http://www.who.int/mediacentre/factsheets/fs117/en/. Acesso em: Julho/2014.

YUE, S.; PILON, P. J.; PHINNEY, B.; CAVADIAS, G. The influence of autocorrelation on the ability to detect trend in hydrological series. Hydrological Processes, New Jersey, v. 16, n. 9, p. 1807-1829, 2002. https://doi.org/10.1002/hyp.1095 